\title{
Nano-mechanical Properties and Pore-Scale Characterization of Different Rank Coals
}

\author{
Yihuai Zhang $\mathbb{D}^{1,2,6}$ Maxim Lebedev, ${ }^{2}$ Gregory Smith, ${ }^{3}$ Yu Jing, ${ }^{4}$ Andreas Busch, \\ and Stefan Iglauer ${ }^{5}$
}

Received 12 June 2019; accepted 2 October 2019

Published online: 18 October 2019

Characterization of coal micro-structure and the associated rock mechanical properties are of key importance for coal seam exploration, coal bed methane development, enhanced coal bed methane production and $\mathrm{CO}_{2}$ storage in deep coal seams. Considerable knowledge exists about coal chemical properties, but less is known about the nanoscale to the microscale structure of coals and how they change with coal strength across coal ranks. Thus, in this study, 3D X-ray micro-computed tomography (with a voxel size of $3.43 \mu \mathrm{m}$ ) and nanoindentation tests were conducted on coal samples of different ranks from peat to anthracite. The micro-structure of peats showed a well-developed pore system with meso- and micropores. The meso-pores essentially disappear with increasing rank, whereas the micro-pores persist and then increase past the bituminous rank. The micro-fracture system develops past the peat stage and by sub-bituminous ranks and changes into larger and mature fracture systems at higher ranks. The nano-indentation modulus showed the increasing trend from low- to high-rank coal with a perfect linear relationship with vitrinite reflectance and is highly correlated with carbon content as expected.

KEY WORDS: ECBM, Coal rank, Micro-CT, Micro-structure, Nano-indentation test.

\section{INTRODUCTION}

Coal is naturally heterogeneous, composing of different components (or coal macerals) which are originally derived from various plant organs. The

\footnotetext{
${ }^{1}$ The Lyell Centre, Heriot-Watt University, Edinburgh, Scotland EH14 4AS, UK.

${ }^{2}$ WA School of Mines: Minerals, Energy and Chemical Engineering, Curtin University, 26 Dick Perry Avenue, Kensington 6151, Australia.

${ }^{3}$ School of Earth and Planetary Sciences, Curtin University, Kent Street, Bentley 6102, Australia.

${ }^{4}$ School of Minerals and Energy Resources Engineering, UNSW, Kensington, Sydney 2052, Australia.

${ }^{5}$ School of Engineering, Edith Cowan University, 270 Joondalup Drive, Joondalup 6027, Australia.

${ }^{6}$ To whom correspondence should be addressed; e-mail: yihuai.zhang@hw.ac.uk
}

physical and chemical properties (or coal rank) will change with increasing burial pressure and temperature (Van Krevelen et al. 1993). Considerable knowledge exists about the chemical changes that occur with increasing coal rank, but how the pore morphology of individual macerals, lithotypes, micro-fractures alter with different coal ranks, and the effects of mineral matter on the porosity and fractures are even less well understood. The microstructure of coals has been studied in detail for certain coal ranks, for example the medium-rank coal (Zhang et al. 2018). However, a wider range of coal ranks will be encountered during the exploration of coal bed methane and carbon geo-sequestration. Therefore, it is necessary to study the petrophysical properties of all ranked coal samples (Zhao et al. 2016; Mathews et al. 2017; Mostaghimi 
et al. 2017; Zhou et al. 2017). The meso- and microporosity, micro-fractures and elastic properties (such as Young's modulus and Poisson's ratio) control the bulk and field-scale estimates of porosity, pore connectivity, permeability, sorption capacity, gas migration, wettability and the seismic analysis of fracture/cleat networks (Al-Yaseri et al. 2017; Kumari et al. 2018; Li et al. 2019).

In the past, coal porosity, pore size distribution or pore throat size distribution has been investigated by traditional invasion techniques such as helium pycnometer, low pressure gas adsorption or mercury injection capillary pressure (MICP) method (Liu et al. 2016). However, these methods are limited, which require the assumptions about pore shape, the encounter problems at low ranks with moisture, and could cause particle breakdown at high pressure invasion (Mahajan and Walker 1978). Nuclear magnetic resonance (NMR) is a non-destructive method which can be used to obtain the pore size distribution (Sun et al. 2016; Yao et al. 2014; Li et al. 2016; Sun et al. 2018). However, it is interpretative and indirect. Scanning electron microscopy (SEM) is adequate for directly imaging the coal micro-structure and in situ analysis with nanoscale resolution, but it is essentially restricted to 2D (Predeanu et al. 2016).

Micro-CT that has been developed recently allows direct imaging of the coal structure in $3 \mathrm{D}$ with high resolution (Mathews et al. 2017; Zhang et al. 2016a; Jing et al. 2017a; Iglauer and Lebedev 2018; Lebedev et al. 2017a, b). The voxel size is typically 1-10 $\mu \mathrm{m}$; thus, percolation thresholds can be estimated more precisely than with 2D SEM measurements (Stauffer 1979). Some studies have been performed on coal using micro-CT imaging: Yao et al. (2009) measured the distributions of the coal matrix constituents; Mathews et al. (2011) analysed the extent of thermal drying-induced deformations in coal; Ramandi et al. (2016) mapped the 3D distribution of minerals in coal from the Bowen Basin, Australia, and compared the results with XRD, SEM, and QEMSCAN data; Zhang et al. (2016a) quantified the coal fracture system as a function of effective stress and the impact on coal permeability and porosity; or Zhang et al. (2016b, c) showed that the micro-cleat system closes by coal matrix swelling with $\mathrm{CO}_{2}$ or water adsorption. However, previous coal studies focused on a single sample or a narrow coal maturity range only, thus a lack of systematic studies in terms of how coal morphology changes with coal rank.
The heterogeneous morphology of coal macerals means that the mechanical properties are also heterogeneous at the micro-, or nanoscale. In addition, coal cleats affect elastic property measurements by both, normal dynamical (e.g. sonic wave) and static methods (e.g. unconfined compressive strength or tri-axial testing). Such effects need to be excluded in coal matrix voxel modelling where effective stress affects the aperture of cleats and are hence important in CBM/ECBM. Hence, modelling input for coal matrix elastic properties needs to be obtained at a smaller scale to obtain coal matrix properties. Such small-scale rock mechanical properties are extremely important for the multiscale fracturing mechanisms, reliable modelling and prediction of the mechanical performance based on rock's structure and composition (e.g. Bobko et al. 2011; Constantinides et al. 2006; Fischer-Cripps 2006; Lebedev et al. 2014; Vialle and Lebedev 2015; Manjunath and Jha 2019). In the past, various hardness measurements such as Vickers indentation tests have been performed on macerals under the microscope over several microns (Van Krevelen 1993). Recently, nanoscale mechanical properties can be obtained by nano-indentation methods which have been applied successfully to natural rocks, such as sandstone (Zhu et al. 2009), limestone (Lebedev et al. 2014; Zhang et al. 2016d), coal (Manjunath and Nair 2015; Manjunath and Jha 2019; Zhang et al. 2017; Yu et al. 2018) and shale (Kumar et al. 2012; Li and Sakhaee-Pour 2016; Liu and Ostadhassan 2017; Zeszotarski et al. 2004). However, there remains a lack of data nanoscale mechanical property measurement correlation with coal rank and with their related anisotropy.

Thus, in this paper, micro-CT imaging at high resolution ( $3.43 \mu \mathrm{m}$ voxel size) has been performed for coals of different ranks (peat, lignite, sub-bituminous, bituminous, anthracite) and nano-indentation tests were performed to measure how the nanomechanical properties varied with coal micro-morphology and rank.

\section{METHODOLOGY}

\section{Samples and Sample Preparation}

The rank in 'coal rank' refers to the steps in a natural and slow process called 'coalification' during the plant matter changes into the material which are denser, harder and more carbon-rich, including an- 
thracite, bituminous, sub-bituminous, lignite and peat (Keshavarz et al. 2017; Pan et al. 2015; Shi et al. 2018). Samples of different coal ranks were selected in this study as follows: a Quaternary peat from Glastonbury, England, to assess the physical characteristics prior to coalification; Paleocene low-rank lignite from North Dakota, USA; Triassic sub-bituminous coal from Pingdingshan, Henan, China; Carboniferous medium-rank bituminous coal from Morgantown, West Virginia, USA; and a Carboniferous high-rank anthracite from Hazelton, Pennsylvania, USA. Proximate analyses results and densities of the studied coal samples (anthracite, bituminous, sub-bituminous and lignite) are summarized in $\mathrm{Ta}$ ble 1 . The surface character of the coal samples, as seen under the SEM (Phenom XL), is illustrated at high magnification in Figure 1. The SEM images for these samples show the typical progression of the physical structure with increasing coal rank. The peat (air-dried) (Fig. 1e) retains large open tissue macro-pores (black) within a huminite matrix. The lignite is mainly huminite composed of a densinite groundmass (generally the lighter coloured matter) and telovitrinite or gelovitrinite bands (darker bands, some with resinous cell contents). The subbituminous sample photograph shows a vitrinite groundmass (grey) and mineral (white, calcite) invasion (Zhang et al. 2016a). The bituminous sample clearly shows that the open macro-pore structure has gone with thin bands of telovitrinite in a groundmass of detrovitrinite, with dispersed mineral matter (white). The anthracite is the most homogeneous sample with no obvious macro-pores, but an anisotropic structure, and very small dispersed mineral grains (white).

The mineral matter in the coals was analysed by XRD using a Bruker-AXS D9 Advance Diffractometer, and the results for each sample are shown in Table 2, where the samples had different minerals. The samples for micro-CT were prepared as small cylindrical coal plugs $(5 \mathrm{~mm}$ in diameter and
$10 \mathrm{~mm}$ in length) drilled parallel to the bedding plane. The samples for the nano-indentation test were cut and carefully polished as cuboid coal blocks $(1 \times \mathrm{w} \times \mathrm{h}=8 \mathrm{~mm} \times 5 \mathrm{~mm} \times 2 \mathrm{~mm})$.

\section{High-Resolution Micro-CT Scanning}

The micro-CT scanning was obtained on small cylindrical coal plugs $(5 \mathrm{~mm}$ diameter, $10 \mathrm{~mm}$ length) by an Xradia Versa XRM instrument. The basic elements for micro-CT scanning include an Xray source, detector and sample stage, where the sample stage is located between the X-ray source and detector and all the parts can move to alter the distance to adjust the magnification during the scanning (e.g. Zhang et al. 2016c; Kong et al. 2018; Jing et al. 2017b; Roshan et al. 2018; Yang et al. 2016; Yang 2018). The output data are displayed as grey scale images where different materials show different effective X-ray attenuation coefficients represented the different ranges of CT numbers. The coal micro-structures can thus be extracted based on the contracts of CT numbers and then quantified with a reconstruction process (Iglauer and Lebedev 2018). The scans were acquired at ambient laboratory conditions (atmospheric pressure and $296 \mathrm{~K}$ ) and high resolution (3.43 $\mu \mathrm{m}$ voxel size) using $2000 \times 2000$ pixel detector for the radiograph acquisition, and an X-ray accelerating voltage of $60 \mathrm{kV}$ was set. Each scanning took around 4-6 h. The obtained micro-CT images were then filtered with a 3D non-local mean filter method for noise removal (Buades et al. 2005) and segmented with a watershed algorithm for phase segmentation (Mangan and Whitaker 1999) using Avizo 9.2 software (Zhang et al. 2016c; Sadeq et al. 2018; Yu et al. 2019). The detail of the image processing is presented in Figure 2 (Zhang et al. 2019).

Table 1. Summary of proximate analyses and densities of the studied coal samples

\begin{tabular}{llcccccc}
\hline Sample & \multicolumn{1}{c}{ Location } & Moisture $(\%)$ & VM $(\%)$ & Ash $(\%)$ & $\mathrm{C}_{\mathrm{f}}(\%)$ & $\mathrm{R}_{\mathrm{o}}(\%)$ & Density $\left(\mathrm{g} / \mathrm{cm}^{3}\right)$ \\
\hline Anthracite & Pennsylvania, USA & 2.6 & 2.9 & 9.7 & 84.9 & 3.9 & 1.3 \\
Bituminous & West Virginia, USA & 2.0 & 32.4 & 6.4 & 59.2 & 0.8 & 1.3 \\
Sub-bituminous & Henan, China & 6.9 & 36.0 & 4.2 & 54.0 & 0.5 & 1.4 \\
Lignite & North Dakota, USA & 16.3 & 34.8 & 7.8 & 41.1 & 0.3 & 1.4 \\
\hline
\end{tabular}

Moisture (\%), moisture content as received; VM (\%), volatile matter yield dry basis; ash (\%), ash content; $\mathrm{C}_{\mathrm{f}}(\%)$, fixed carbon content; Ro $(\%)$, vitrinite reflectance; density $\left(\mathrm{g} / \mathrm{cm}^{3}\right)$, bulk density $\rho$ 


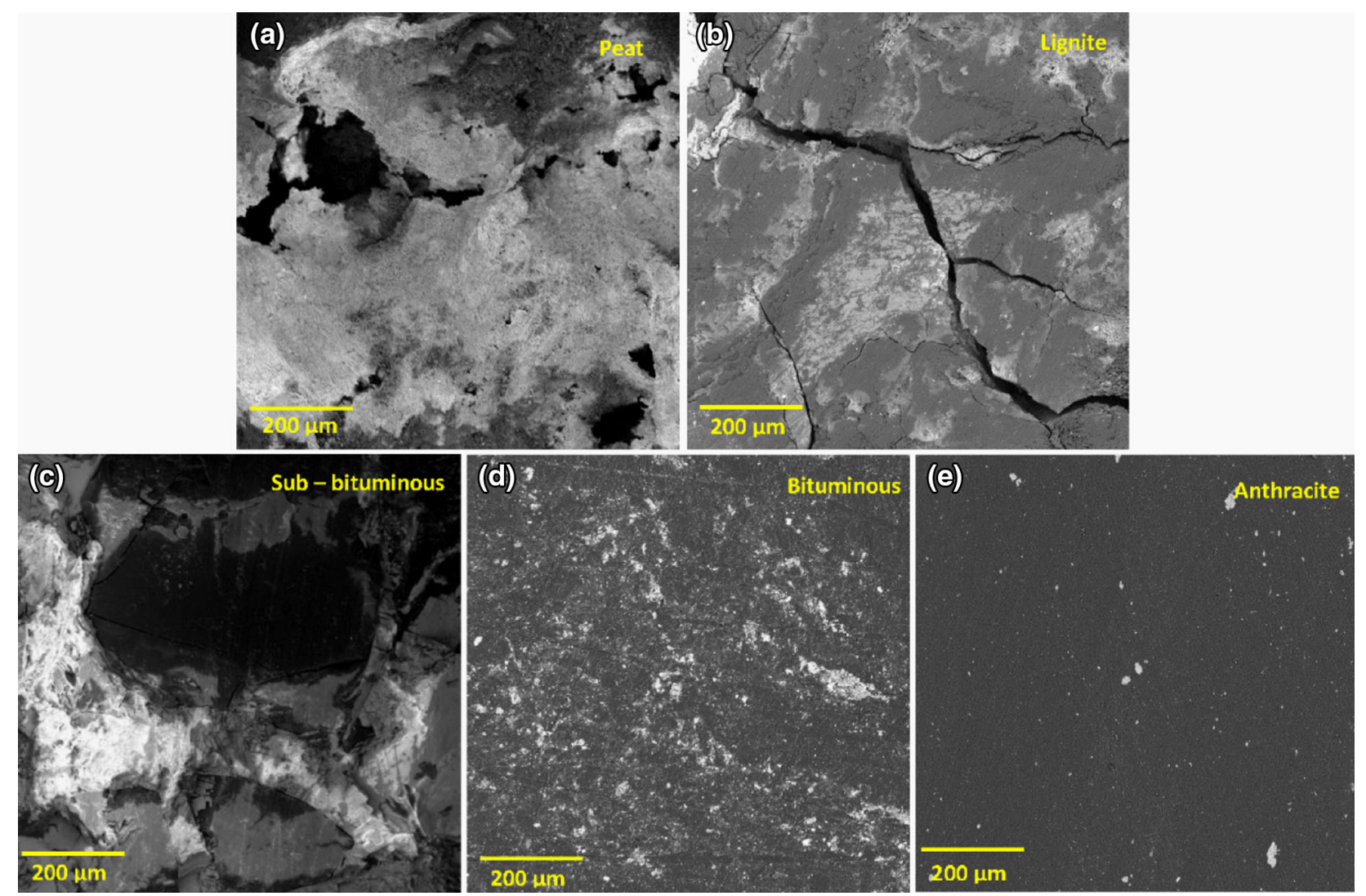

Fig. 1. SEM images for the coal samples from low to high rank: (a) peat, (b) lignite, (c) sub-bituminous, (d) bituminous and (e) anthracite.

Table 2. XRD data for the inorganic mineral matter fraction in the coal samples (displayed in wt $\%$ of the mineral matter fraction)

\begin{tabular}{lcccc}
\hline Minerals & Anthracite & Bituminous & Sub-bituminous & Lignite \\
\hline Illite & 34 & 17 & - & 3 \\
Kaolinite & 24 & 30 & 96 & 24 \\
Calcite & - & - & 1 & - \\
Quartz & 21 & - & - & - \\
Anatase & 21 & 6 & - & - \\
Montmorillonite & - & 6 & - & - \\
Illite-montmorillonite & - & & & - \\
\hline
\end{tabular}

\section{Nano-indentation Test}

An IBIS Nano-indentation System from Fischer-Cripps Laboratories equipped with a Berkovich nano-indenter was used for the nanoindentation measurements (Fig. 3a). The coal samples for this analysis were polished with a diamond abrasive paste $(3 \mu \mathrm{m})$ and then mounted on the sample stage of the system. The indenter (Fig. 3b) penetrates into the sample as the loading stress increases from 0 to $4 \mathrm{mN}$, producing plastic or elastic deformation to the sample surface. The indenter is then retracted, releasing the loading stress. By recording the 'loading-unloading' force $(P)$ and corresponding penetration depth $(h)$, a penetration curve is recorded, as shown in Figure 3c. 


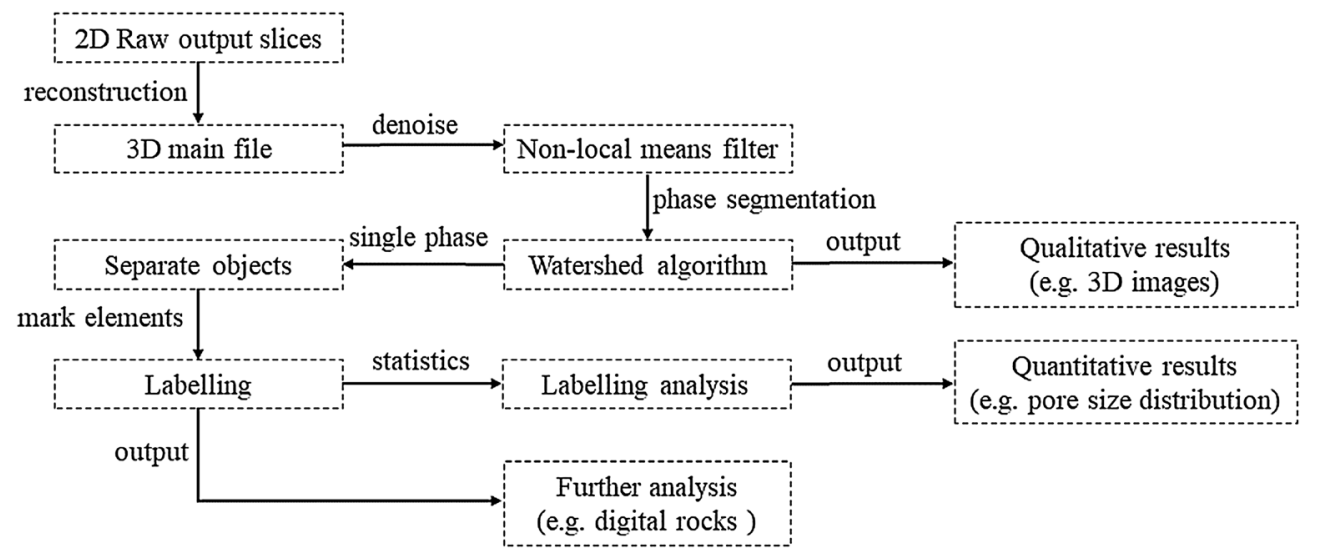

Fig. 2. Flowchart for the image processing (Zhang et al. 2019).
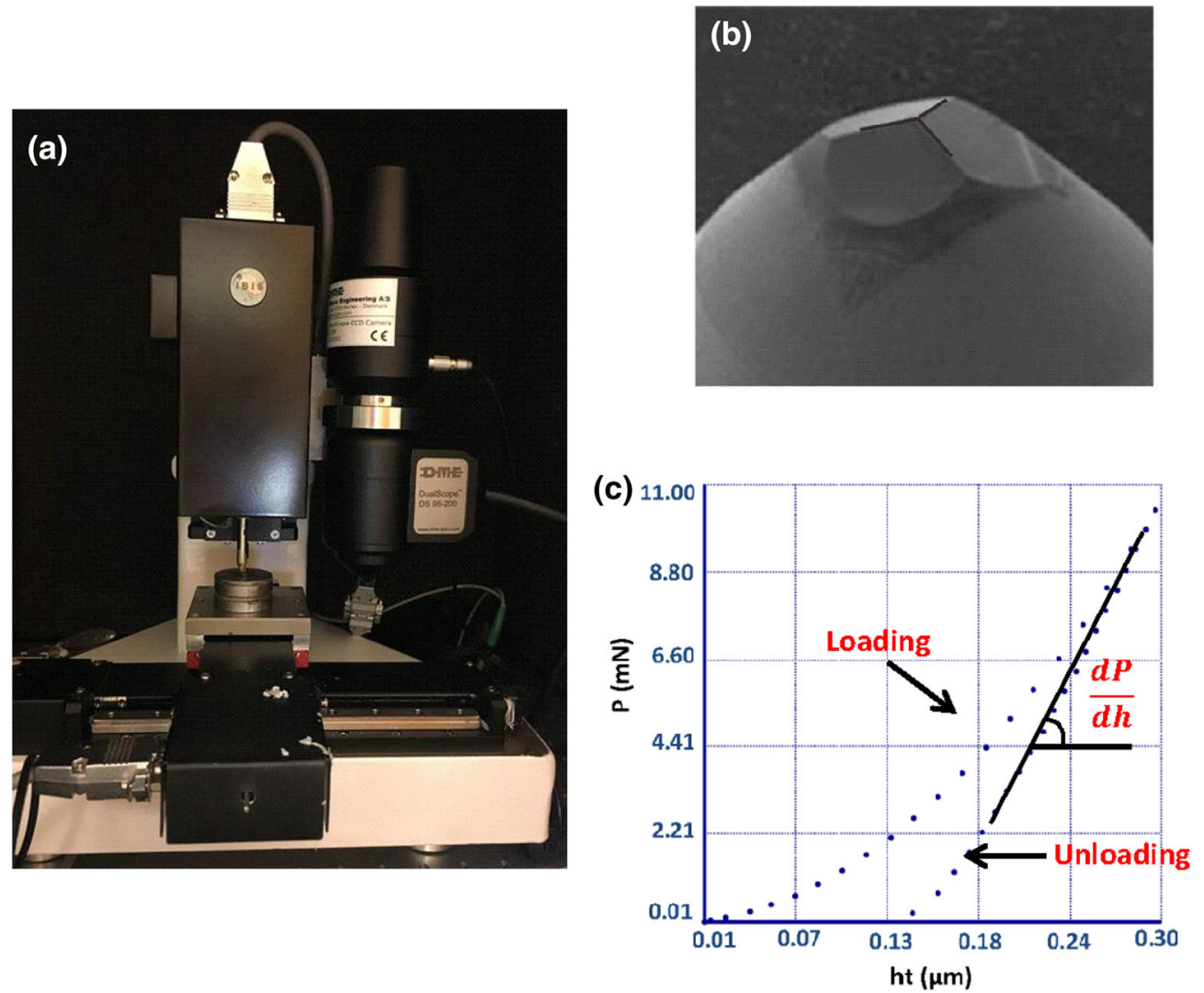

Fig. 3. (a) Photograph of the IBIS nano-indentation system. (b) Tip of the Berkovich nano-indenter. (c) A typical $P$ (indentation force)-ht (indentation depth) curve for a calibration sample (quartz), with Young's modulus $72.5 \mathrm{GPa}$, Poisson's ratio 0.17 and a measured indentation modulus of $74.5 \mathrm{GPa}$. 
The method proposed by Oliver and Pharr (2011) based on the Sneddon solutions was used for analysing the resulting data, where the indentation modulus $E_{M}$ (also called reduced modulus) is defined as:

$$
\frac{1}{E_{M}}=\frac{1-v^{2}}{E}+\frac{1-v_{i}^{2}}{E_{i}}
$$

where $E$ is the Young's modulus, $v$ is the Poisson ratio, $E_{i}$ is the Young's modulus of the indenter and $v_{i}$ is Poisson's ratio of the indenter. The indentation modulus $E_{M}$ is obtained from the measured $P-h$ curve (Fischer-Cripps 2011):

$$
E_{M}=\frac{\mathrm{d} P}{\mathrm{~d} h} \frac{1}{2 \beta} \frac{\sqrt{\pi}}{\sqrt{A}}
$$

where $\mathrm{A}$ is the contact area, $d P / d h$ is the slope of the unloading curve when the maximum force $P_{\max }$ is applied and the maximum penetration depth $h_{\max }$ is achieved (see $\mathrm{c}$ in Fig. 3), $\beta$ is equal to 1.034 for the Berkovich indenter (King 1987).

\section{RESULTS AND DISCUSSION}

\section{Variation in Pore-Scale Morphology with Coal Rank}

The original grey scale raw micro-CT images (voxel size: $3.43 \mu \mathrm{m}$ ) were obtained on the different ranks of coals with the $2 \mathrm{D}$ raw micro-CT slices presented in Figure 4, and the 3D raw images are shown in Figure 5. The coals can be recognized as three main phases according to their CT contrast (Xray relative radiodensity): pores/fractures (dark grey/black), coal matrix (mid grey) and minerals (white/light grey). Clearly, different ranks of coal appear to have different micro-morphologies. While peat is moderately bedded, it also contains uncompacted plant tissue vitrinite precursor, comprising intact plant tissue (telovitrinite) and fragmented plant tissue (detrovitrinite) (Fig. 4a). In peat, there is a high proportion of large and medium pores/ fractures, which could reach to $0.5 \mathrm{~mm}$ in diameter, forming a well-connected pore system. A minor detrital or crystalline mineral phase occurs (probably clay or silt sized quartz) that is dispersed through the plant material or trapped in the cell lumens. (Note that because there is no agreement for the porous media size classification in the micro-CT

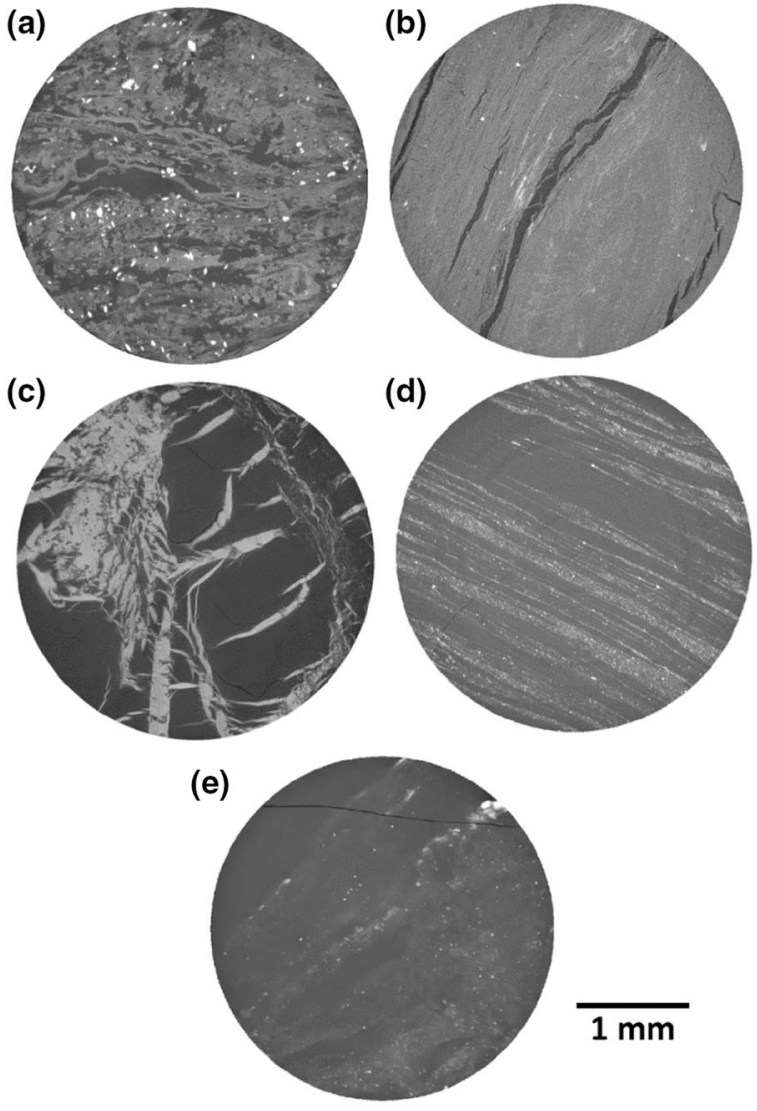

Fig. 4. $2 \mathrm{D}$ cross-sectional micro-CT images $(3.43 \mu \mathrm{m}$ voxel size) of the various coal samples: (a) peat; (b) lignite; (c) subbituminous; (d) bituminous; (e) anthracite.

scale, in order for the analysis to be convenient, we set the diameter less than $50 \mu \mathrm{m}$ as small pores/ fractures, $50-200 \mu \mathrm{m}$ as medium pores/fractures, larger than $200 \mu \mathrm{m}$ as large pores/fractures.)

The lignite sample has undergone burial compaction and gelification losing all large porosity and most of the medium porosity. The micro-structure is now laminated parallel to bedding and perpendicular to the overburden pressure with only minor medium pores left subparallel to bedding (not to be confused with the large desiccation cracks that may have formed from air-drying that also preferentially open parallel to bedding). Some incipient microcleats have developed perpendicular to the bedding almost exclusively in the telovitrinite bands (Fig. 4b), which is expected with gelification by this coal rank (Smith 1981; Widera 2014). The organic macerals can be seen faintly, indicating that they have slightly different average densities. The minerals comprise quartz grains with minor kaolin 

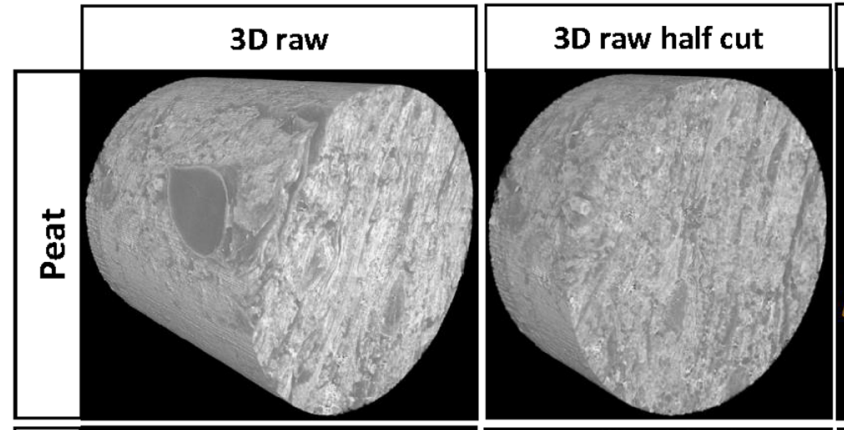

High density part
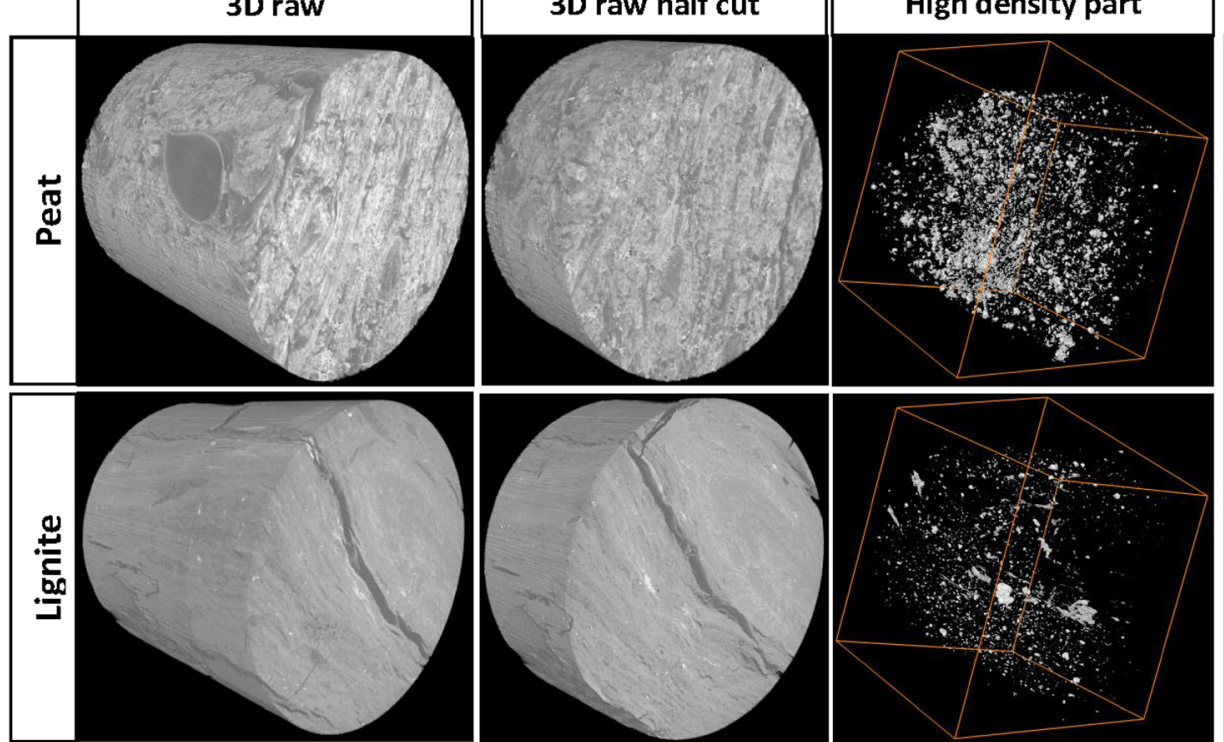

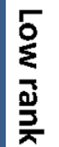
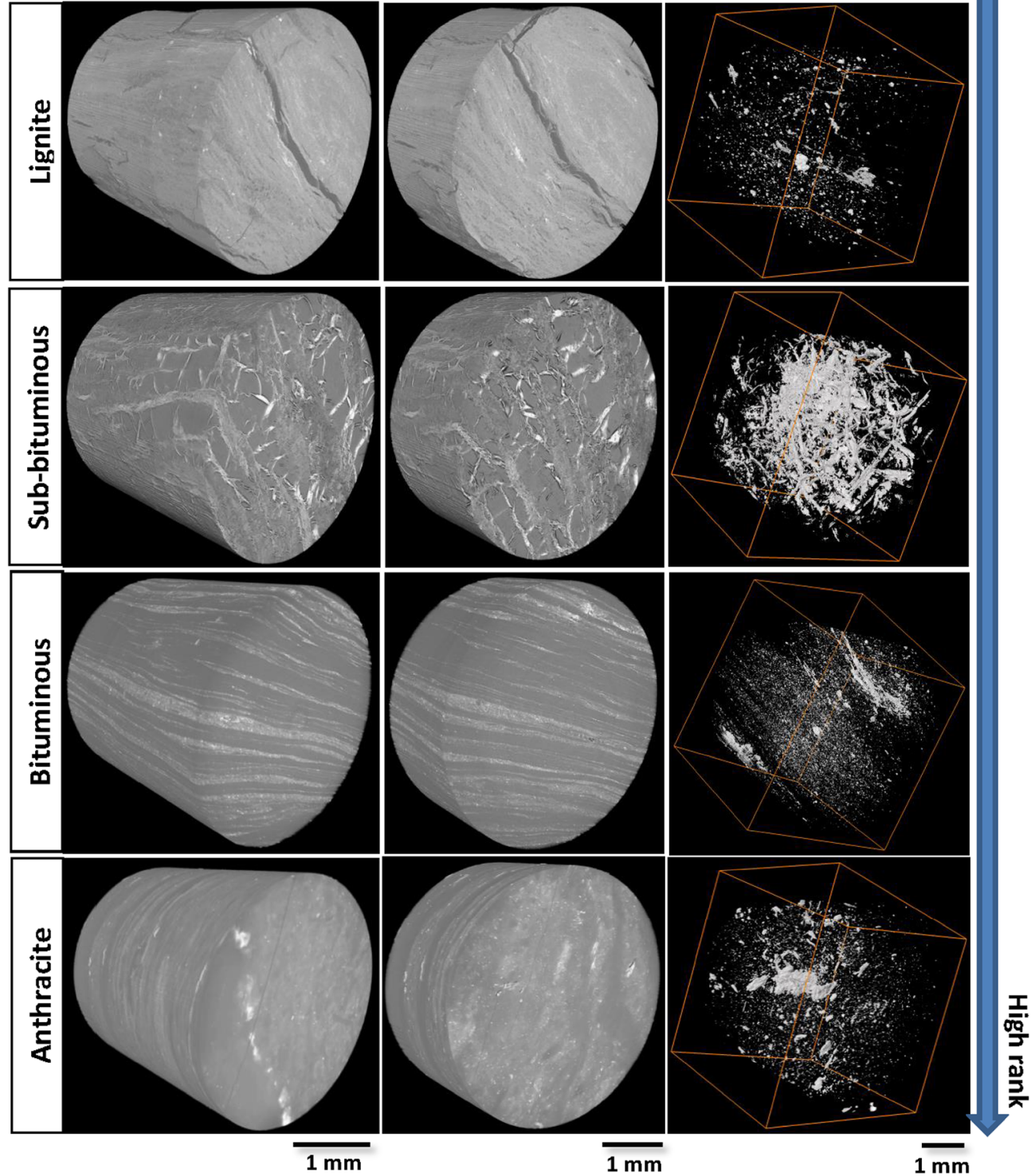

Fig. 5. 3D visualizations of the raw micro-CT images of the various coals studied. The nominal image resolution is $3.43 \mu \mathrm{m}$. The high-density part shows the volume elements which have a high relative radiodensity (white). 
mainly occurring between the laminae and appear to have grown in situ.

The micro-CT plug sub-sampled from the subbituminous coal sample is mostly massive telovitrinite with no visible remaining medium pores and moisture reduced to $7 \%$. The plug was taken in a section with a high amount of carbonate mineral matter (compared to coal sample which had much lower ash \%, such heterogeneous character is expected in coal) occurring as calcite veins infilling the original cleat in the telovitrinite with finer-grained calcite grown along or oblique to the bedding planes. This is a complicated strain pattern (Fig. 4), showing that the early formed cleats have been modified by growth during extension and cross-cut by later sigmoidal and branching calcite veins, suggesting extension from right-lateral shear stress. These micro-structures are best seen using the $3 \mathrm{D}$ micro-CT volumes (Fig. 5) that indicate cleat presence as a 3D network of small-scale face and micro-butt cleats (Su et al. 2001; Karacan and Okandan, 2000; SolanoAcosta 2007; Zhang et al. 2016a).

The bituminous coal micro-CT plug shows highly compacted thin vitrinite laminae alternating with laminae dominated by mineral matter dispersed in an organic matrix, giving the coal a finely laminated texture. The mineral matter (ash 6.4\%) comprises quartz and clays, including illite as well as kaolinite and montmorillonite (Table 2), suggesting the conversion of some clays to illite induced by the higher burial temperatures. No obvious medium pores remain, and porosity may be original, from plant tissue cell lumens or detrovitrinite bands.

The anthracite shows no relict medium pores and weak bedding features. The mineral matter is dispersed more uniformly through the coal matrix though still within certain vitrinite bands. The sample contains mineralized (white) fracture as shown in Figure 5, and the oblique fine black fracture in Figure 4 may be an artefact of handling and preparation or original.

The 2D and 3D segmented images are shown in Figures 6 and 7, respectively. The volume fractions of three phases (pore/fractures, matrix and minerals) are given in Table 3. The results clearly show how the fracture porosity rapidly decreases with coal rank, from $17 \%$ in peat to $6 \%$ in lignite to $<0.3 \%$ in the sub-bituminous and higher rank coal. Interestingly, these results were able to confirm a minimum coal matrix pore volume within the bituminous coal increasing slightly again in the anthracite, which has the same trend in coal cleat spacing (Laubach et al. 1998). We thus suggested the scale cannot affect the fracture porosity change trend along with coal rank.

Coal porosity and fracture systems are particularly important for coal bed methane (CBM) pro-

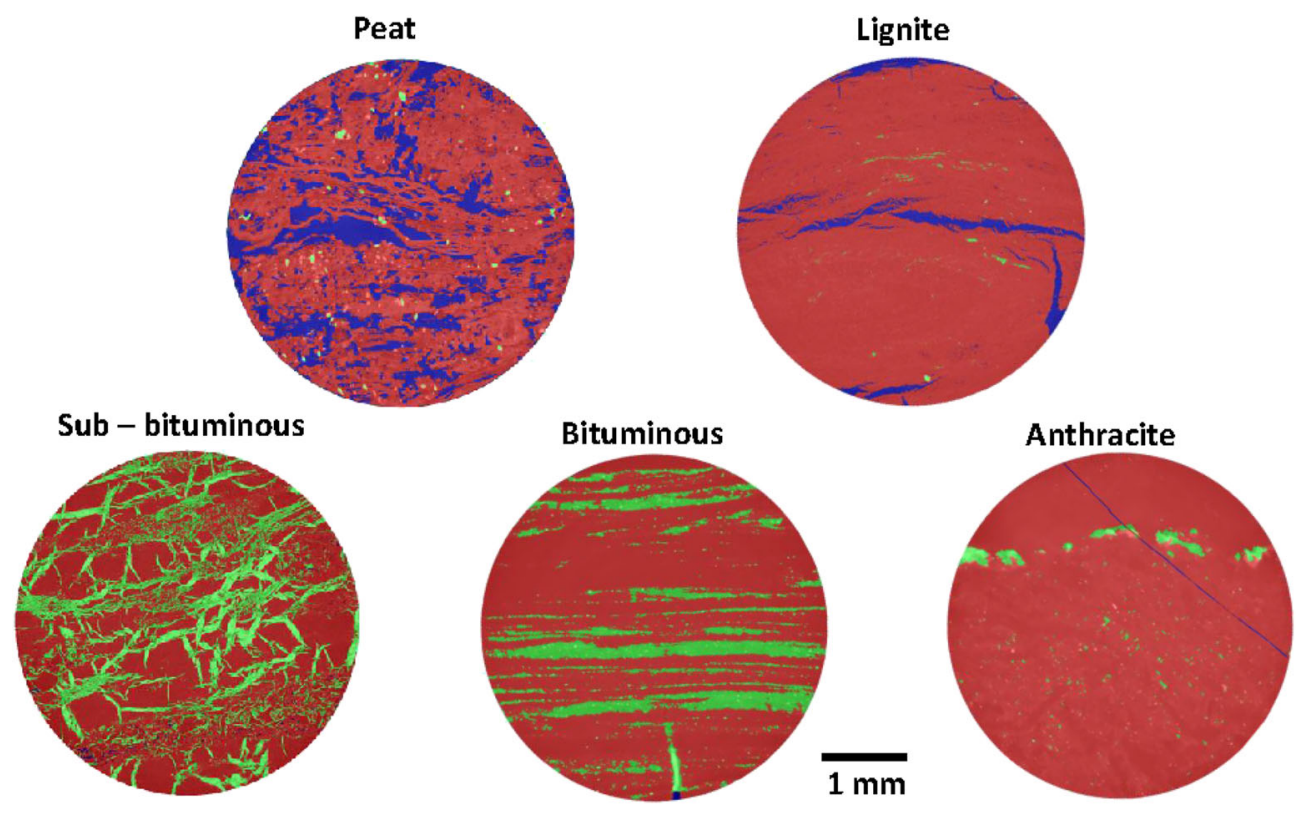

Fig. 6. Segmented 2D slices: coal (red), minerals (green), pores/fractures (blue). 

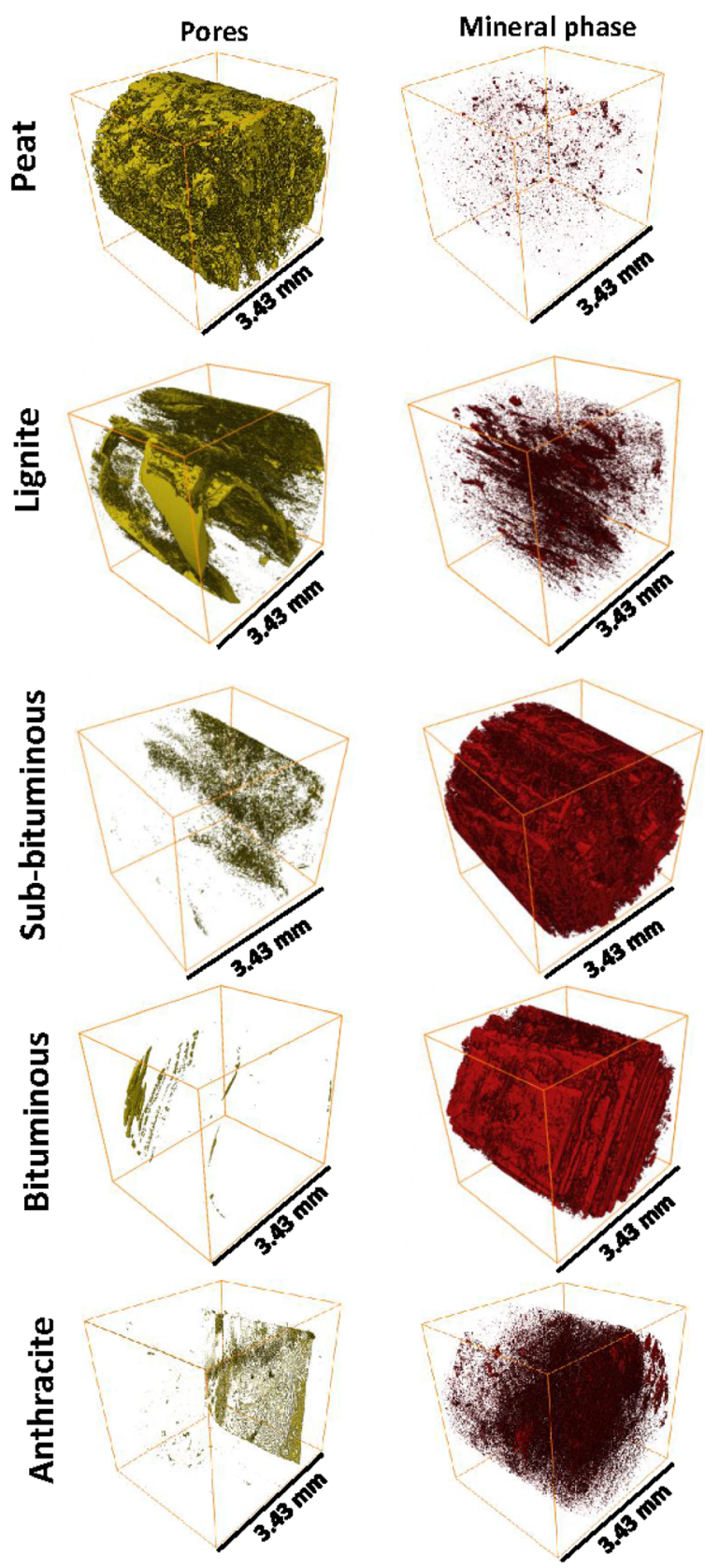

Fig. 7. 3D morphologies of the pore space and mineral matter for each coal rank (nominal resolution is $3.43 \mu \mathrm{m}$ ).

duction, enhanced coal bed methane production (ECBM) and carbon dioxide storage in coal seams because they directly influence the permeability and production efficiency (Mostaghimi et al. 2017; Zhang et al. 2016a; Li et al. 2017). The pore size distributions (PSD, which also includes the microfractures or cleats) of the different coal rank samples
Table 3. Phase volumes for the different coal ranks measured on the 3D micro-CT images

\begin{tabular}{lccc}
\hline Sample & $\begin{array}{c}\text { Pores/fractures } \\
(\%)\end{array}$ & $\begin{array}{c}\text { Coal matrix } \\
(\%)\end{array}$ & $\begin{array}{c}\text { Mineral } \\
(\%)\end{array}$ \\
\hline Anthracite & 0.33 & 97.01 & 2.66 \\
Bituminous & 0.06 & 81.44 & 18.50 \\
$\begin{array}{l}\text { Sub-bitumi- } \\
\quad \text { nous }\end{array}$ & 0.30 & 69.62 & 30.08 \\
Lignite & & & \\
Peat & 6.16 & 93.23 & 0.61 \\
\hline
\end{tabular}

from micro-CT scanning are shown in Figure 8. The peat contained both the highest number of pores and also the largest pores (which was approximately $1000 \mu \mathrm{m}^{3}$ ), while lignite has a large number of pores, an order of magnitude smaller, with a mode of $110 \mu \mathrm{m}^{3}$ and most pore volumes ranging between 10 and $100 \mu \mathrm{m}^{3}$. In the sub-bituminous coal, the pore sizes had reduced across the range, but especially in the $10-1000 \mu \mathrm{m}^{3}$ range. The bituminous coal has a small number of pores remaining in the $10-1000 \mu^{3}$ range but very few above that size, and the anthracite has very few pores across the range. Similarly, the medium-rank coal (sub-bituminous and bituminous) contained the highest amount of crystallized minerals (see Fig. 7). Such mineral was secondary sedimentation and filled the macro-cleats after the coal seam formed (Zhang et al. 2016a; SolanoAcosta et al. 2007), thus reducing the void volume.

\section{Nano-mechanical Properties of the Various Coal Ranks}

We measured 1000 indentation results points on each rank coal sample, where typically up to 50 test points underwent invalid measuring (e.g. when the indenter went inside the pores/fractures). The results for the peat have not been included as a frequency distribution, because only 31 of the measurements were acceptable due to the high number of large pores existed, and the insufficient degree of compaction and resulting peat strength which was not sufficient to stop the loading indenter from pushing through the solid into the underlying large pores. The distributions of the indentation moduli $E_{M}$ (GPa) for the lignite, sub-bituminous, bituminous and anthracite samples are illustrated in Figure 9a, and the average indentation moduli for each coal sample are presented in Figure 9b. 

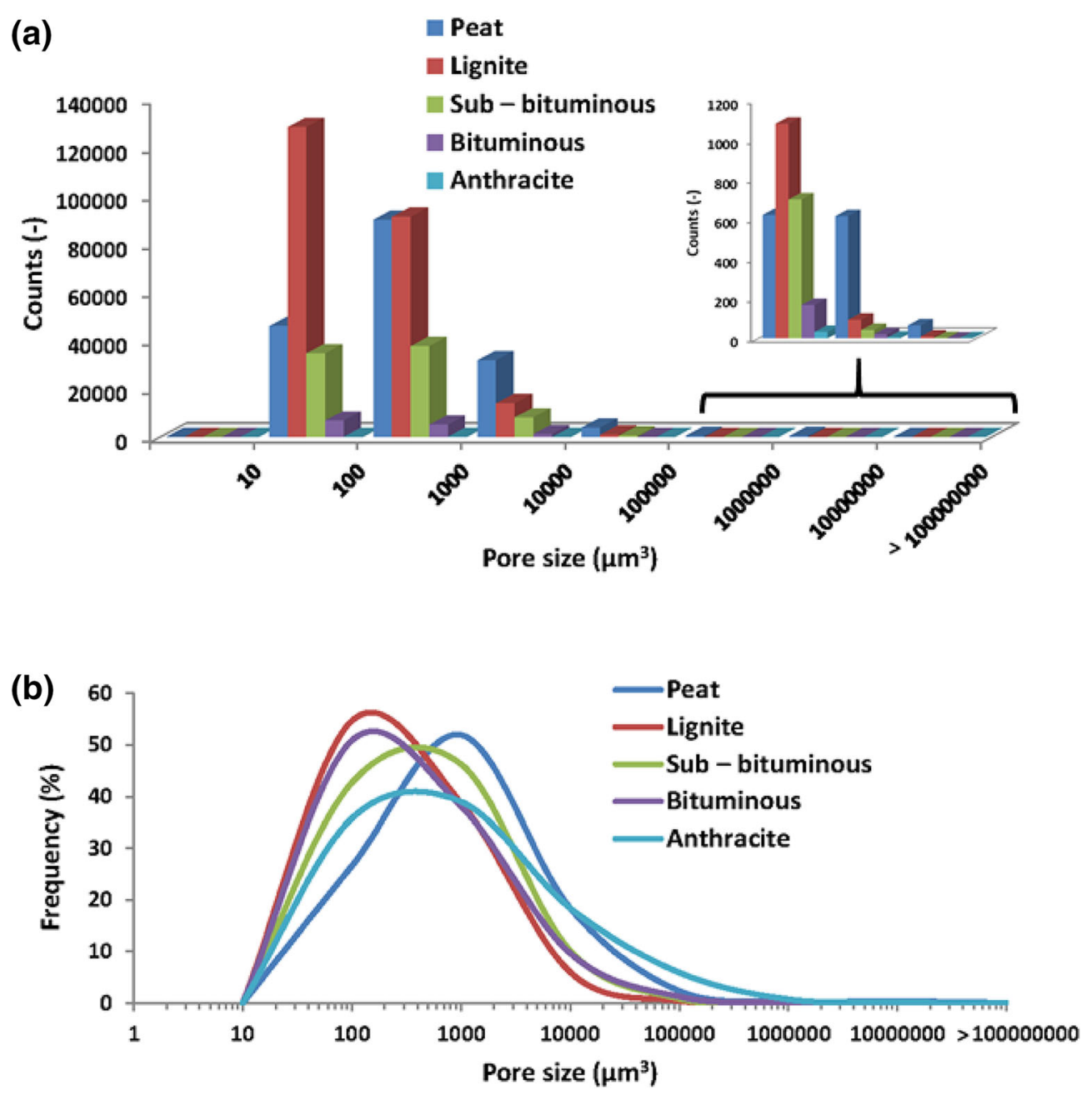

Fig. 8. Pore size distributions for different rank coal samples: (a) by counts (-); (b) by frequency (\%).

The lignite $E_{M}$ distribution has a mode below $5 \mathrm{GPa}$ but broadened towards higher values, indicating that it contains a spread of maceral sub-types, which display various compaction densities, and possible some mineral matter. The sub-bituminous coal $E_{M}$ distribution is narrower with a mode of $5 \mathrm{GPa}$ but also multi-modal with higher humps around $10 \mathrm{GPa}$ or higher due to the calcite and other mineral matter, which have higher elastic moduli than the coal macerals (Zhang et al. 2016d; Zhang et al. 2018; Lebedev et al. 2014). Similarly, the bituminous coal $E_{M}$ distribution is narrow with a mode around $7 \mathrm{GPa}$, while it does not show higher hump values (compared with sub-bituminous coal); this may be due to it having a lower crystallized mineral content as evidenced from the microstructural morphology results (Fig. 5). The $E_{M}$ distribu- tion for the anthracite is much broader and moving to higher value overall with a mode around $10 \mathrm{GPa}$. Figure $9 \mathrm{~b}$ shows that the average indentation elastic moduli decrease with decreasing coal rank. The elastic moduli value of anthracite is two times higher than that of lignite and ten times higher than the peat.

The samples are not meant to be a comprehensive set covering the full range of coal ranks and coal types. However, the average nano-indentation results for each coal type (calculated from $\sim 1000$ results for each sample) are plotted against fixed carbon content and vitrinite reflectance in Figure 10 to display potential relationships. The results confirmed that increasing elastic moduli $E_{M}$ occurred with decreasing moisture content and volatile matter yield and increasing mineral matter and carbon 
content. The indentation elastic moduli $E_{M}$ had an excellent linear relationship (Fig. 10d) with the fixed carbon content $\mathrm{C}_{\mathrm{f}}\left(\mathrm{R}^{2}=0.99\right)$, expressed as:

$$
E_{M}=0.55+0.11 C_{f}
$$

This is plausible as the organic carbon structure and crystallinity are expected to be the main control on the coal strength characteristics, especially when
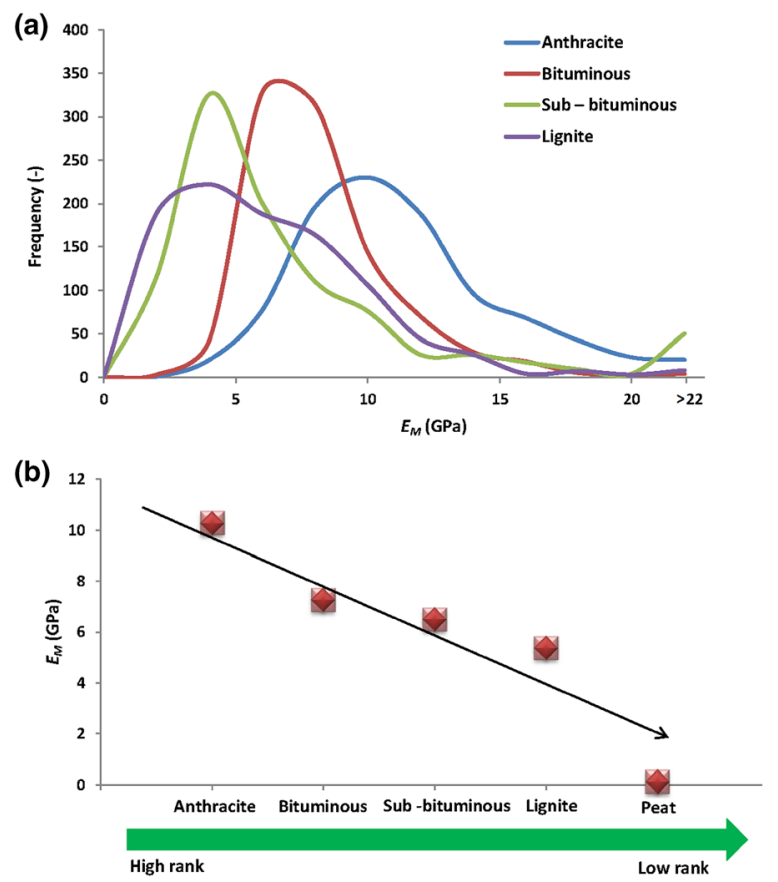

Fig. 9. (a) Distributions of indentation elastic moduli $E_{M}$ (GPa) for coals of different coal ranks. (b) Average indentation elastic moduli $E_{M}(\mathrm{GPa})$ as a function of coal rank. the influence of mineral matter is removed. And the indentation elastic moduli $\mathrm{E}_{\mathrm{M}}$ also had a linear relationship (Fig. 10e) with coal rank (by vitrinite reflectance Ro (\%) where $\left.\mathrm{R}^{2}=0.93\right)$, expressed as:

$$
E_{M}=5.70+1.19 R_{O}
$$

We thus suggested these experiments matched equations could have a more general application that should be investigated in the future on more different samples.

\section{CONCLUSIONS}

Coal micro-structure and coal rock mechanical properties are extremely important for coal utilization, for instance in mining, coke production, deep drilling, $\mathrm{CBM} / \mathrm{ECBM}$ and $\mathrm{CO}_{2}$ geo-sequestration (Karacan and Okandan 2001; Busch et al. 2019; Li et al. 2017). However, coal is a highly complex heterogeneous material composed of both, organic and inorganic matter, and it can change significantly from low to high rank. The chemical composition of coal is well studied (Van Krevelen 1993), whereas coal micro-structure and its rock mechanical properties related to the coal rank are only poorly understood, especially at the micro- and nanoscale.

We thus report here a high-resolution micro-CT imaging analysis and associated nano-indentation tests for a wide range of coal ranks, from peat and lignite to bituminous coals and anthracite, to expand fundamental understanding in this area. The microCT images clearly depict the change in maceral structure with compaction and how the associated micro-scale porosity reduces, first quickly with burial
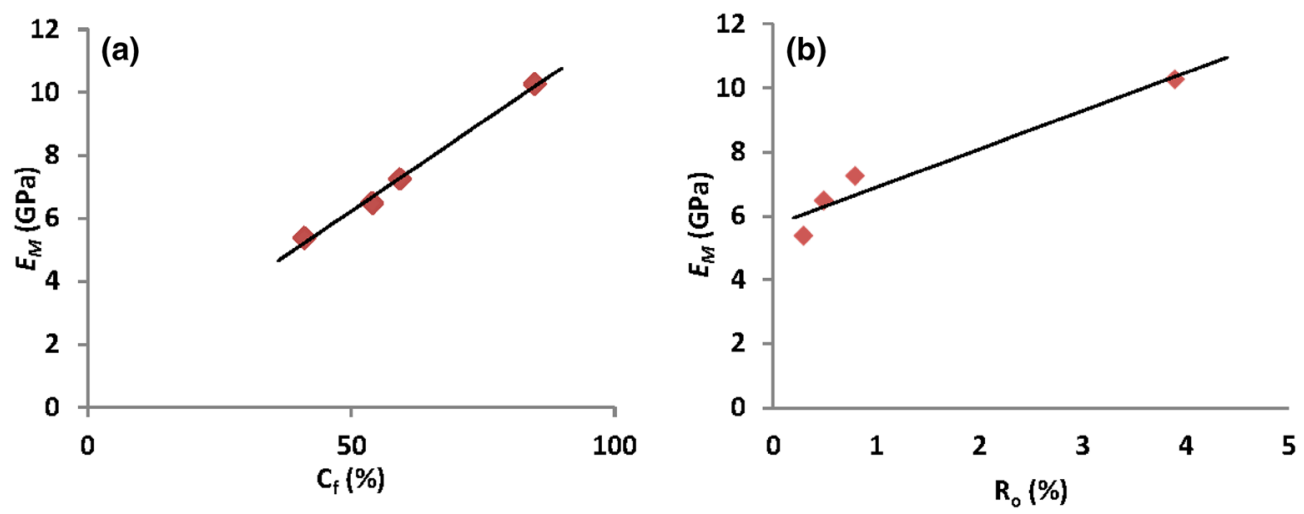

Fig. 10. Average indentation elastic moduli $\left(E_{M}\right)$ for each coal type plotted versus: (a) fixed carbon content $\mathrm{C}_{\mathrm{f}}(\%)$; (b) vitrinite reflectance $\mathrm{R}_{\mathrm{o}}(\%)$. 
and then more slowly with gelification and coalification. The $3 \mathrm{D}$ visualizations offer the ability to see the pore network and to quantitatively analyse the morphology of the various phases of organic matter, mineral matter and porosity across the range of sizes in micro-scales. Clearly, the micro-CT results confirm that the medium-rank coal has the lowest pore/ fracture volume fractions, which has the same trend in coal cleat spacing at previous studies (see Laubach et al. 1998), while the average pore size decreases with increasing coal rank. More specifically, the large pore size ranges decrease with increasing coal rank, with large and medium pore sizes disappearing by bituminous coal ranks diminishing the interconnected pore network, whereas the micropore structure is maintained or begins to increase at high coal ranks. In contrast, cleats are absent from soft brown coals developing in the lignite (hard brown coal) stage through into the bituminous coal ranks to become the main permeability conduit. Both, the original pores and the cleats, can be sites of diagenetic mineral crystallization, and this seems particularly the case in structurally affected coals such as near faults. The nano-indentation results showed that the indentation moduli increase with an increase in coal rank built-up, and such indentation moduli highly correlated with vitrinite reflectance and fixed carbon content inside the coal.

\section{ACKNOWLEDGMENTS}

The measurements were performed at Curtin University using the micro-CT system and nano-indentation system courtesy of the National Geosequestration Laboratory (NGL) of Australia. Funding for the facilities was provided by the Australian Federal Government. This work was also supported by resources provided by the Pawsey Supercomputing Centre with funding from the Australian Government and the Government of Western Australia.

\section{OPEN ACCESS}

This article is distributed under the terms of the Creative Commons Attribution 4.0 International License (http://creativecommons.org/licenses/by/ $4.0 /$ ), which permits unrestricted use, distribution, and reproduction in any medium, provided you give appropriate credit to the original author(s) and the source, provide a link to the Creative Commons license, and indicate if changes were made.

\section{REFERENCES}

Al-Yaseri, A. Z., Roshan, H., Xu, X., Zhang, Y., Sarmadivaleh, M., Lebedev, M., et al. (2017). Coal wettability after $\mathrm{CO}_{2}$ injection. Energy \& Fuels, 31(11), 12376-12382.

Bobko, C. P., Gathier, B., Ortega, J. A., Ulm, F. J., Borges, L., \& Abousleiman, Y. N. (2011). The nanogranular origin of friction and cohesion in shale-a strength homogenization approach to interpretation of nanoindentation results. International Journal for Numerical and Analytical Methods in Geomechanics, 35(17), 1854-1876.

Buades, A., Coll, B., \& Morel, J.-M. (2005). A non-local algorithm for image denoising. In IEEE computer society conference on Computer vision and pattern recognition, CVPR 2005. IEEE. 60-65.

Busch, A., Han, F., \& Magill, C. R. (2019). Paleofloral dependence of coal methane sorption capacity. International Journal of Coal Geology, 211, 103232.

Constantinides, G., Chandran, K. R., Ulm, F.-J., \& Van Vliet, K. (2006). Grid indentation analysis of composite microstructure and mechanics: Principles and validation. Materials Science and Engineering A, 430(1), 189-202.

Fischer-Cripps, A. C. (2006). Critical review of analysis and interpretation of nanoindentation test data. Surface \& Coatings Technology, 200(14), 4153-4165.

Fischer-Cripps, A. (2011). Nanoindentation. Berlin: Springer.

Iglauer, S., \& Lebedev, M. (2018). High pressure-elevated temperature x-ray micro-computed tomography for subsurface applications. Advances in Colloid and Interface Science, 256, 393-410.

Jing, Y., Armstrong, R. T., \& Mostaghimi, P. (2017a). Roughwalled discrete fracture network modelling for coal characterisation. Fuel, 191, 442-453.

Jing, Y., Armstrong, R. T., \& Mostaghimi, P. (2017b). Digital coal: Generation of fractured cores with microscale features. Fuel, 207, 93-101.

Karacan, C. Ö., \& Okandan, E. (2000). Fracture/cleat analysis of coals from Zonguldak basin (northwestern Turkey). relative to the potential of coalbed methane production. International Journal of Coal Geology, 44(2), 109-125.

Karacan, C. O., \& Okandan, E. (2001). Adsorption and gas transport in coal microstructure: Investigation and evaluation by quantitative X-ray CT imaging. Fuel, 80(4), 509-520.

Keshavarz, A., Sakurovs, R., Grigore, M., \& Sayyafzadeh, M. (2017). Effect of maceral composition and coal rank on gas diffusion in Australian coals. International Journal of Coal Geology, 173, 65-75.

King, R. (1987). Elastic analysis of some punch problems for a layered medium. International Journal of Solids and Structures, 23(12), 1657-1664.

Kong, L., Ostadhassan, M., Li, C., \& Tamimi, N. (2018). Pore characterization of 3D-printed gypsum rocks: A comprehensive approach. Journal of Materials Science, 53(7), 50635078.

Kumar, V., Curtis, M. E., Gupta, N., Sondergeld, C. H., \& Rai, C. S. (2012). Estimation of elastic properties of organic matter in Woodford Shale through nanoindentation measurements. In SPE Canadian unconventional resources conference: Society of petroleum engineers. 
Kumari, W. G. P., Ranjith, P. G., Perera, M. S. A., Li, X., Li, L. H., Chen, B. K., et al. (2018). Hydraulic fracturing under high temperature and pressure conditions with micro CT applications: Geothermal energy from hot dry rocks. Fuel, 230, 138-154.

Laubach, S., Marrett, R., Olson, J., \& Scott, A. (1998). Characteristics and origins of coal cleat: A review. International Journal of Coal Geology, 35(1), 175-207.

Lebedev, M., Wilson, M. E., \& Mikhaltsevitch, V. (2014). An experimental study of solid matrix weakening in water-saturated Savonnières limestone. Geophysical Prospecting, 62(6), 1253-1265.

Lebedev, M., Zhang, Y., Mikhaltsevitch, V., Inglauer, S., \& Rahman, T. (2017a). Residual trapping of supercritical CO2: Direct pore-scale observation using a low cost pressure cell for micro computer tomography. Energy Procedia, 114, 49674974.

Lebedev, M., Zhang, Y., Sarmadivaleh, M., Barifcani, A., AlKhdheeawi, E., \& Iglauer, S. (2017b). Carbon geosequestration in limestone: Pore-scale dissolution and geomechanical weakening. International Journal of Greenhouse Gas Control, 66, 106-119.

Li, X., Fu, X., Ranjith, P. G., \& Xu, J. (2019). Stress sensitivity of medium-and high volatile bituminous coal: An experimental study based on nuclear magnetic resonance and permeabilityporosity tests. Journal of Petroleum Science and Engineering, 172, 889-910.

Li, H., Lin, B., Yang, W., Zheng, C., Hong, Y., Gao, Y., et al. (2016). Experimental study on the petrophysical variation of different rank coals with microwave treatment. International Journal of Coal Geology, 154, 82-91.

Li, Z., Liu, D., Cai, Y., Ranjith, P. G., \& Yao, Y. (2017). Multiscale quantitative characterization of 3-D pore-fracture networks in bituminous and anthracite coals using FIB-SEM tomography and X-ray $\mu$-CT. Fuel, 209, 43-53.

Li, W., \& Sakhaee-Pour, A. (2016). Macroscale Young's moduli of shale based on nanoindentations. Petrophysics, 57(06), 597603.

Liu, K., \& Ostadhassan, M. (2017). Microstructural and geomechanical analysis of Bakken shale at nanoscale. Journal of Petroleum Science and Engineering, 153, 133-144.

Liu, P., Yuan, Z., \& Li, K. (2016). An improved capillary pressure model using fractal geometry for coal rock. Journal of Petroleum Science and Engineering, 145, 473-481.

Mahajan, O. P., \& Walker, P. L. (1978). Porosity of coals and coal products. In C. Karr (Ed.), Analytical methods for coal and coal products (pp. 125-162). New York: Academic Press.

Mangan, A. P., \& Whitaker, R. T. (1999). Partitioning 3D surface meshes using watershed segmentation. IEEE Transactions on Visualization and Computer Graphics, 5(4), 308-321.

Manjunath, G. L., \& Jha, B. (2019). Nanoscale fracture mechanics of gondwana coal. International Journal of Coal Geology, 204, 102-112.

Manjunath, G., \& Nair, R. R. (2015). Implications of the 3D micro scale coal characteristics along with Raman stress mapping of the scratch tracks. International Journal of Coal Geology, $141,13-22$.

Mathews, J. P., Campbell, Q. P., Xu, H., \& Halleck, P. (2017). A review of the application of X-ray computed tomography to the study of coal. Fuel, 209, 10-24.

Mathews, J. P., Pone, J. D. N., Mitchell, G. D., \& Halleck, P. (2011). High-resolution X-ray computed tomography observations of the thermal drying of lump-sized subbituminous coal. Fuel Processing Technology, 92(1), 58-64.

Mostaghimi, P., Armstrong, R. T., Gerami, A., Hu, Y., Jing, Y., Kamali, F., et al. (2017). Cleat-scale characterisation of coal: An overview. Journal of Natural Gas Science and Engineering, 39, 143-160.
Oliver, W. C., \& Pharr, G. M. (2011). Measurement of hardness and elastic modulus by instrumented indentation: Advances in understanding and refinements to methodology. Journal of Materials Research, 19, 3.

Pan, J., Zhao, Y., Hou, Q., \& Jin, Y. (2015). Nanoscale pores in coal related to coal rank and deformation structures. Transport in Porous Media, 107(2), 543-554.

Predeanu, G., Popescu, L. G., Abagiu, T. A., Panaitescu, C., Valentim, B., \& Guedes, A. (2016). Characterization of bottom ash of pliocene lignite as ceramic composites raw material by petrographic, SEM/EDS and Raman microspectroscopical methods. International Journal of Coal Geology, $168,131-145$

Ramandi, H. L., Mostaghimi, P., Armstrong, R. T., Saadatfar, M. \& Pinczewski, W. V. (2016). Porosity and permeability characterization of coal: a micro-computed tomography study. International Journal of Coal Geology, 154, 57-68.

Roshan, H., Masoumi, H., Zhang, Y., Al-Yaseri, A. Z., Iglauer, S., Lebedev, M., et al. (2018). Microstructural effects on mechanical properties of shaly sandstone. Journal of Geotechnical and Geoenvironmental Engineering, 144(2), 06017019.

Sadeq, D., Iglauer, S., Lebedev, M., Rahman, T., Zhang, Y., \& Barifcani, A. (2018). Experimental pore-scale analysis of carbon dioxide hydrate in sandstone via X-ray micro-computed tomography. International Journal of Greenhouse Gas Control, 79, 73-82.

Shi, X., Pan, J., Hou, Q., Jin, Y., Wang, Z., Niu, Q., et al. (2018). Micrometer-scale fractures in coal related to coal rank based on micro-CT scanning and fractal theory. Fuel, 212, 162-172.

Smith, G.C. (1981). Tertiary and upper cretaceous coals and coal measure sediments in the bass and gippsland basins. Ph.D. Thesis, Wollongong University, (p.338).

Solano-Acosta, W., Mastalerz, M., \& Schimmelmann, A. (2007). Cleats and their relation to geologic lineaments and coalbed methane potential in Pennsylvanian coals in Indiana. International Journal of Coal Geology, 72(3), 187-208.

Stauffer, D. (1979). Scaling theory of percolation clusters. Physics Reports, 54(1), 1-74.

Su, X., Feng, Y., Chen, J., \& Pan, J. (2001). The characteristics and origins of cleat in coal from western north China. International Journal of Coal Geology, 47(1), 51-62.

Sun, X., Yao, Y., Liu, D., Elsworth, D., \& Pan, Z. (2016). Interactions and exchange of $\mathrm{CO} 2$ and $\mathrm{H} 2 \mathrm{O}$ in coals: an investigation by low-field NMR relaxation. Scientific Reports, 6, 19919.

Sun, X., Yao, Y., Liu, D., \& Zhou, Y. (2018). Investigations of CO 2-water wettability of coal: NMR relaxation method. International Journal of Coal Geology, 188, 38-50.

Van Krevelen, D. W. (1993). Coal: Typology, chemistry, physics, constitution (3rd ed., p. 979). Amsterdam: Elsevier.

Vialle, S., \& Lebedev, M. (2015). Heterogeneities in the elastic properties of microporous carbonate rocks at the microscale from nanoindentation tests. In SEG technical program expanded abstracts 2015: Society of exploration geophysicists. 3279-3284.

Widera, M. (2014). What are cleats? Preliminary studies from the konin lignite mine. Miocene of central Poland. Geologos, 20(1), 3-12.

Yang, S. Q. (2018). Fracturing mechanism of compressed hollowcylinder sandstone evaluated by X-ray micro-CT scanning. Rock Mechanics and Rock Engineering, 51(7), 2033-2205.

Yang, Y., Zhang, W., Gao, Y., Wan, Y., Su, Y., An, S., et al. (2016). Influence of stress sensitivity on microscopic pore structure and fluid flow in porous media. Journal of Natural Gas Science and Engineering, 36, 20-31.

Yao, Y., Liu, D., Che, Y., Tang, D., Tang, S., \& Huang, W. (2009). Non-destructive characterization of coal samples from China 
using microfocus X-ray computed tomography. International Journal of Coal Geology, 80(2), 113-123.

Yao, Y., Liu, D., \& Xie, S. (2014). Quantitative characterization of methane adsorption on coal using a low-field NMR relaxation method. International Journal of Coal Geology, $131,32-40$.

Yu, H., Zhang, Y., Lebedev, M., Han, T., Verrall, M., Wang, Z., et al. (2018). Nanoscale geomechanical properties of western Australian coal. Journal of Petroleum Science and Engineering, 162, 736-746.

Yu, H., Zhang, Y., Lebedev, M., Wang, Z., Li, X., Squelch, A., et al. (2019). X-ray micro-computed tomography and ultrasonic velocity analysis of fractured shale as a function of effective stress. Marine and Petroleum Geology, 110, 472-482.

Zeszotarski, J. C., Chromik, R. R., Vinci, R. P., Messmer, M. C., Michels, R., \& Larsen, J. W. (2004). Imaging and mechanical property measurements of kerogen via nanoindentation. Geochimica et Cosmochimica Acta, 68(20), 4113-4119.

Zhang, Y., Lebedev, M., Al-Yaseri, A., Yu, H., Xu, X., \& Iglauer, S. (2018). Characterization of nanoscale rock mechanical properties and microstructures of a Chinese sub-bituminous coal. Journal of Natural Gas Science and Engineering, 52, $106-116$.

Zhang, Y., Lebedev, M., Jing, Y., Yu, H., \& Iglauer, S. (2019). Insitu X-ray micro-computed tomography imaging of the microstructural changes in water-bearing medium rank coal by supercritical $\mathrm{CO}_{2}$ flooding. International Journal of Coal Geology, 203, 28-35.

Zhang, Y., Lebedev, M., Sarmadivaleh, M., Barifcani, A., \& Iglauer, S. (2016a). Swelling-induced changes in coal microstructure due to supercritical CO2 injection. Geophysical Research Letters, 43(17), 9077-9083.
Zhang, Y., Lebedev, M., Sarmadivaleh, M., Barifcani, A., \& Iglauer, S. (2016d). Change in geomechanical properties of limestone due to supercritical $\mathrm{CO}_{2}$ injection. In SPE Asia pacific oil and gas conference and exhibition: Society of petroleum engineers.

Zhang, Y., Lebedev, M., Sarmadivaleh, M., Barifcani, A., Rahman, T., \& Iglauer, S. (2016b). Swelling effect on coal micro structure and associated permeability reduction. Fuel, 182, $568-576$.

Zhang, Y., Xu, X., Lebedev, M., Sarmadivaleh, M., Barifcani, A., \& Iglauer, S. (2016c). Multi-scale X-ray computed tomography analysis of coal microstructure and permeability changes as a function of effective stress. International Journal of Coal Geology, 165, 149-156.

Zhang, Y., Zhang, Z., Sarmadivaleh, M., Lebedev, M., Barifcani, A., Yu, H., et al. (2017). Micro-scale fracturing mechanisms in coal induced by adsorption of supercritical $\mathrm{CO}_{2}$. International Journal of Coal Geology, 175, 40-50.

Zhao, J., Xu, H., Tang, D., Mathews, J. P., Li, S., \& Tao, S. (2016). Coal seam porosity and fracture heterogeneity of macrolithotypes in the Hancheng block, eastern margin, Ordos basin, China. International Journal of Coal Geology, 159, 18-29.

Zhou, S., Liu, D., Cai, Y., Yao, Y., \& Li, Z. (2017). 3D characterization and quantitative evaluation of pore-fracture networks of two Chinese coals using FIB-SEM tomography. International Journal of Coal Geology, 174, 41-54.

Zhu, W., Fonteyn, M., Hughes, J., \& Pearce, C. (2009). Nanoindentation study of resin impregnated sandstone and early-age cement paste specimens. Nanotechnology in Construction, 3, 403-408. 